\title{
STRUCTURAL DEFECTS IN THE FeCOYB AMORPHOUS ALLOYS
}

\author{
DEFEKTY STRUKTURALNE W AMORFICZNYCH STOPACH FeCoYB
}

\begin{abstract}
The aim of this work was to determine the nature of the structural defects that have a major influence on the magnetisation process within the investigated alloys. The structure of the alloys in the as-quenched state was investigated by means of X-ray diffractometry. It was confirmed that the samples were amorphous. The magnetisation was measured within magnetic fields ranging from 0 to $2 \mathrm{~T}$ using a vibrating sample magnetometer (VSM). The investigation of the 'magnetisation in the area close to ferromagnetic saturation' showed that, for this class of alloys, the magnetisation process in strong magnetic fields is connected with the following two influences: 1) Firstly, the rotation of the magnetic moments in the vicinity of the defects, which are the sources of the short-range stresses, and, 2) The dumping of the thermally-induced spin waves by the magnetic field. In the case of the $\mathrm{Fe}_{63} \mathrm{Co}_{10} \mathrm{Y}_{7} \mathrm{~B}_{20}$ alloy, the magnetisation process is connected with both point and linear defects, whereas for the $\mathrm{Fe}_{64} \mathrm{Co}_{10} \mathrm{Y}_{6} \mathrm{~B}_{20}$ alloy, only with linear defects. This suggests that the size of the defects, determining the character of the magnetisation in the vicinity of ferromagnetic saturation, depends on the atomic packing density. On the basis of analysis of the magnetisation curves, the spin wave stiffness parameter $\left(\mathrm{D}_{\mathrm{sp}}\right)$ was calculated.

Keywords: amorphous alloy, X-ray diffractometry, magnetisation process, structural defects, spin wave stiffness parameter
\end{abstract}

Celem pracy było określenie defektów strukturalnych mających decydujący wpływ na proces magnesowania stopów. Strukturę stopów w stanie po zestaleniu badano za pomocą rentgenowskiej analizy dyfrakcyjnej. Stwierdzono, że badane próbki były bezpostaciowe.. Magnetyzację mierzono w silnym polu magnetycznym (0-2 T) przy użyciu magnetometru wibracyjnego (VSM). Badania magnetyzacji w pobliżu ferromagnetycznego nasycenia wykazały, że proces przemagnesowania badanych stopów w silnych polach magnetycznych związany jest z obrotami momentów magnetycznych w pobliżu defektów będących źródłami naprężeń bliskiego zasięgu oraz $\mathrm{z}$ thumieniem przez pole magnetyczne termicznie wzbudzanych fal spinowych. W przypadku stopu $\mathrm{Fe}_{63} \mathrm{Co}_{10} \mathrm{Y}_{7} \mathrm{~B}_{20}$ za proces magnesowania w silnych polach odpowiedzialne są defekty punktowe oraz liniowe, natomiast w stopie $\mathrm{Fe}_{64} \mathrm{Co}_{10} \mathrm{Y}_{6} \mathrm{~B}_{20}$ tylko defekty liniowe. Wskazuje to, że wielkość defektów decydujących o charakterze zmian magnetyzacji w pobliżu ferromagnetycznego nasycenia zależy od gęstości upakowania atomów. Na podstawie analizy krzywych namagnesowania wyznaczono parametr sztywności fali spinowej $\mathrm{D}_{\mathrm{sp}}$.

\section{Introduction}

The bulk amorphous alloys (also known as 'volume amorphous alloys') comprise many elements. In order to obtain a strong proclivity towards creation of the amorphous state, the atomic radii of the main component elements should differ by more than $12 \%$. In addition, the elements should be characterised by negative mixing heat [1-3].

The bulk amorphous alloys are characterised by unique magnetic properties, which strongly depend on the chemical composition of the alloys [4-8]. In these alloys, long-range atomic order does not exist, although the long-range order of the spin magnetic moments could be observed.
Due to the presence of structural defects, the sample is not magnetised to saturation, even when under the influence of strong magnetic fields. These defects are the source of shortrange stresses. As a result of the magnetoelastic interactions between stresses and magnetisation, a non-collinear magnetic structure is present. Within strong magnetic field, in the vicinity of the so-called 'approach to ferromagnetic saturation', an increase in the magnetic field results in an increase in the magnetisation; this results from the microrotations of the magnetic moments around these defects. The further, slow increase in the value of magnetisation is associated with the dumping of the thermally-induced spin waves.

\footnotetext{
* CZESTOCHOWA UNIVERSITY OF TECHNOLOGY, INSTITUTE OF PHYSICS, FACULTY OF PRODUCTION ENGINEERING AND MATERIALS TECHNOLOGY, 19 ARMII KRAJOWEJ AV., 42-200 CZĘSTOCHOWA, POLAND

** CZESTOCHOWA UNIVERSITY OF TECHNOLOGY, INSTITUTE OF MATERIALS ENGINEERING, FACULTY OF PRODUCTION ENGINEERING AND MATERIALS TECHNOLOGY,

19 ARMII KRAJOWEJ AV., 42-200 CZĘSTOCHOWA, POLAND

\# Corresponding author: 23kasia1@wp.pl
} 
According to the H. Kronmüller theorem [9-12], the magnetisation $(\mathrm{m} \mathrm{M})$ of the amorphous alloy within a strong magnetic field $\left(\mathrm{m}_{0} \mathrm{H}\right)$ can be described by an equation called the 'law of the approach to ferromagnetic saturation':

$$
\mu_{0} M(H)=\mu_{0} M_{S}\left(1-\sum_{n=1}^{4} a_{n / 2} / \mu_{0} H^{n / 2}\right)+b\left(\mu_{0} H\right)^{1 / 2}
$$

where: $M_{s}-$ spontaneous magnetisation, $\mu_{0}-$ magnetic permeability of a vacuum, $H$ - magnetic field, $a_{1 / 2}, a_{1}, a_{2}-$ gradient coefficients of the linear fit related with the type of defect, $b$ - gradient coefficient of the linear fit related to thermal dumping of the spin-waves by the strong magnetic field.

The coefficient $b$ is related to the spin wave stiffness parameter $D_{s p}$ by the following equation, [13]:

$$
b=3,54 g \mu_{0} \mu_{B}\left(\frac{1}{4 \pi D_{s p}}\right)^{3 / 2} k T\left(g \mu_{B}\right)^{1 / 2}
$$

where: $g$ - Lande splitting factor, $\mu_{B}$ - Bohr magneton.

The $D_{s p}$ parameter is connected with the changes in the nearest neighbourhood of the iron atoms and is described by the following equation [14]:

$$
D_{s p}=\frac{1}{3} S J_{e x}(a) a^{2} z_{m}
$$

where:

$\mathrm{S}$ - the spin value in the distance from the central atom;

$\mathrm{J}_{\mathrm{ex}}-$ the local exchange integral;

$\mathrm{a}$ - the distance to the nearest-neighbour atoms;

$\mathrm{z}_{\mathrm{m}}$ - the number of nearest-neighbour magnetic atoms.

The aim of this paper was to investigate the magnetic properties of the $\mathrm{Fe}_{63} \mathrm{Co}_{10} \mathrm{Y}_{7} \mathrm{~B}_{20}$ and $\mathrm{Fe}_{64} \mathrm{Co}_{10} \mathrm{Y}_{6} \mathrm{~B}_{20}$ bulk amorphous alloys. The type of structural defects, influencing their magnetisation process, and the spin wave stiffness parameter $D_{s p}$ also have been established.

\section{Methods and materials}

The samples used in the investigations were produced by an injection-suction-casting method. The elements used in the production process of the investigated alloys were of high purity: 99.98 at.\% Fe, 99.99 at.\% Co, and 99.99 at.\% Y. The element boron was added to the alloy in the form of FeB alloy. The obtained samples of the FeCoYB alloys were produced in the form of rods of length $2 \mathrm{~cm}$ and diameter $1 \mathrm{~mm}$.

The structure of the samples in the as-quenched state was investigated by means of a Bruker "D8 Advance" X-ray diffractometer, equipped with a $\mathrm{CuK}_{\alpha}$ lamp. The investigations were performed over the $2 \Theta$ range, from $30^{\circ}$ to $120^{\circ}$, using a measurement step of $0.02^{\circ}$. The measurement time was $5 \mathrm{~s}$ per step. Investigations into magnetisation as a function of magnetic field induction (up to $2 \mathrm{~T}$ ), were performed using a LakeShore vibrating sample magnetometer (VSM), the latter having a measurement accuracy of $0.5 \%$ per $0.001 \mathrm{G}$ step. This device has been widely used for measurement of soft magnetic properties. The results of the magnetic investigations, carried out using strong magnetic fields, were interpreted according to the Kronmüller theorem.

\section{Results and discussion}

Fig. 1 shows X-ray diffraction patterns for the samples of the investigated alloys.

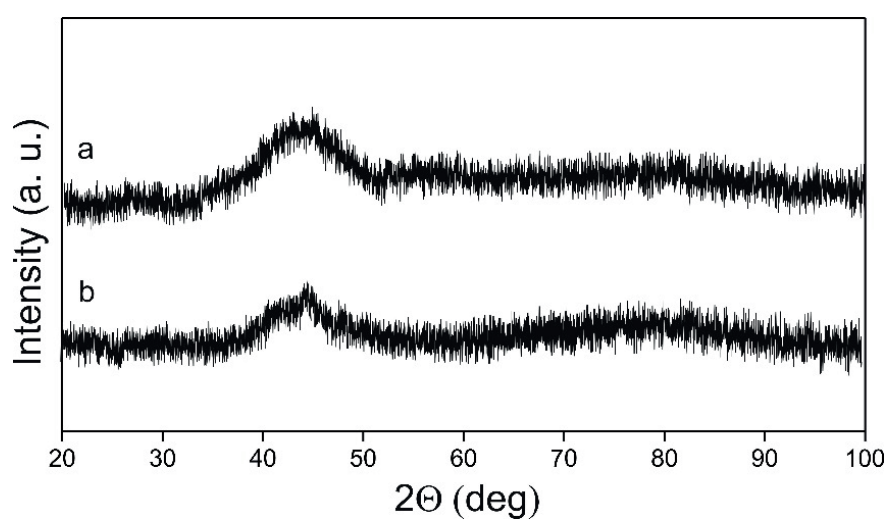

Fig. 1. X-ray diffraction patterns for the investigated alloys of $\mathrm{Fe}_{63} \mathrm{Co}_{10} \mathrm{Y}_{7} \mathrm{~B}_{20}(\mathrm{a})$ and $\mathrm{Fe}_{64} \mathrm{Co}_{10} \mathrm{Y}_{6} \mathrm{~B}_{20}(\mathrm{~b})$, in the as-quenched state

The X-ray diffraction patterns are typical for amorphous alloys, since there is an absence of narrow maxima which would be characteristic of crystalline materials. For each investigated alloy, only a broad maximum at $2 \Theta \approx 45^{\circ}$ could be observed.

The initial magnetisation curves, in the vicinity of the area called the 'approach to ferromagnetic saturation', were analysed according to the H. Kronmüller theorem. In amorphous materials, the structural defects are in the form of so-called 'free volumes' (point defects) or 'quasidislocational dipoles' (linear defects). These defects are the source of the short- and medium-range stresses and they influence the magnetisation behaviour within strong magnetic fields. According to the H. Kronmüller theorem, a linear relationship of reduced magnetisation as a function of $\mu_{0} \mathrm{H}^{-1 / 2}$ indicates the presence of point defects in a sample, whereas a linear relationship of reduced magnetisation as a function of $\mu_{0} \mathrm{H}^{-1}$ indicates the presence of quasidislocational dipoles $[15,16,17]$.

Figs. 2-5 present the magnetisation curves for the bulk amorphous alloy of $\mathrm{Fe}_{63} \mathrm{Co}_{10} \mathrm{Y}_{7} \mathrm{~B}_{20}$. 


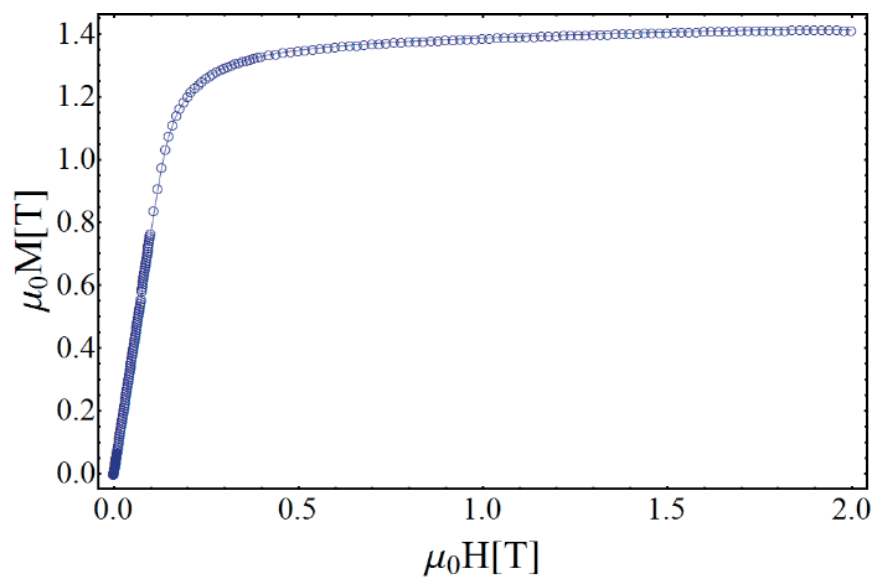

Fig. 2. Magnetisation $\left(\mathrm{m}_{0} \mathrm{M}\right)$ as a function of the magnetising field $\mu_{0} \mathrm{H}$ for the bulk amorphous alloy of $\mathrm{Fe}_{63} \mathrm{Co}_{10} \mathrm{Y}_{7} \mathrm{~B}_{20}$ in the as-quenched state

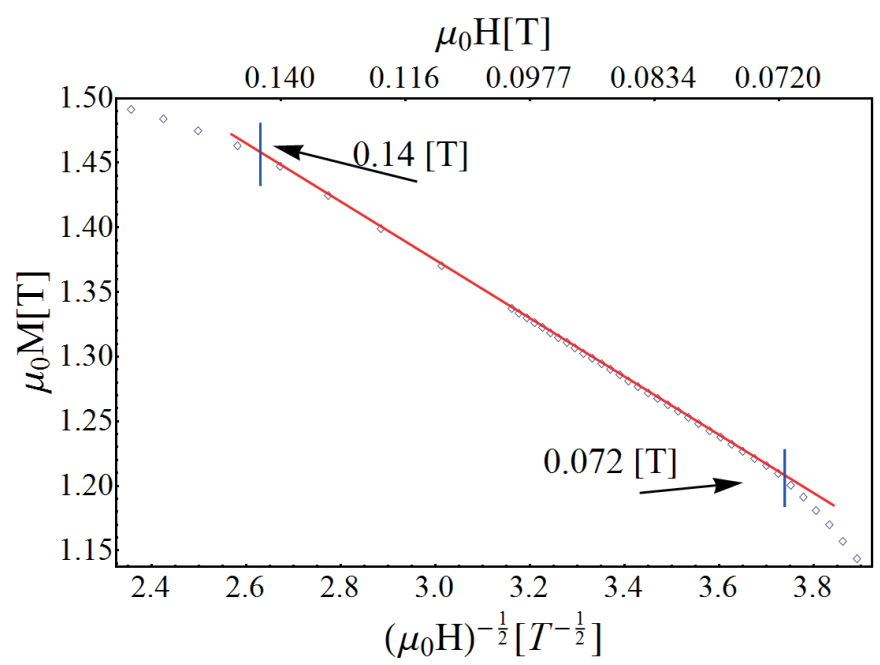

Fig. 3. The high-field magnetisation $m_{0} \mathrm{M}\left(\left(\mu_{0} H\right)^{-1 / 2}\right)$ for the bulk amorphous alloy of $\mathrm{Fe}_{63} \mathrm{Co}_{10} \mathrm{Y}_{7} \mathrm{~B}_{20}$ in the as-quenched state

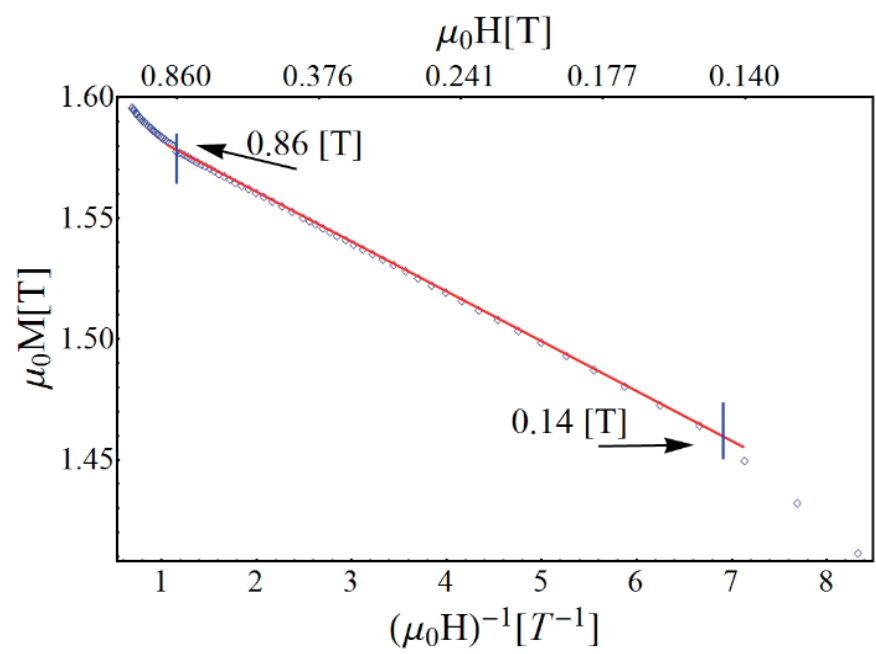

Fig. 4. The high-field magnetisation curve $m_{0} M\left(\left(\mu_{0} H\right)^{-1}\right)$ for the sample of the bulk amorphous alloy of $\mathrm{Fe}_{63} \mathrm{Co}_{10} \mathrm{Y}_{7} \mathrm{~B}_{20}$ in the asquenched state

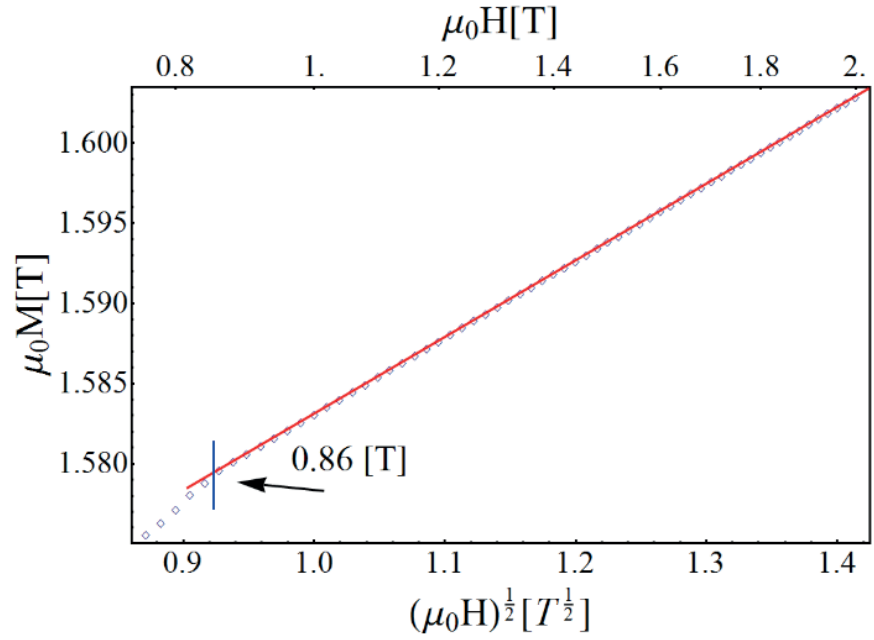

Fig. 5. The high-field magnetisation curve $m_{0} \mathrm{M}\left(\left(\mu_{0} \mathrm{H}\right)^{1 / 2}\right)$ for the sample of the bulk amorphous alloy of $\mathrm{Fe}_{63} \mathrm{Co}_{10} \mathrm{Y}_{7} \mathrm{~B}_{20}$ in the asquenched state.

Under the influence of weaker magnetic fields in the 'approach to saturation magnetisation' area, a linear relationship of $m_{0} M\left(\left(\mu_{0} H\right)^{-1 / 2}\right)$ was observed (Fig. 3); this indicates that, within the range of magnetic field strength from $0.072 \mathrm{~T}$ to $0.14 \mathrm{~T}$, point defects represent the predominant influence on the magnetisation process. Within the induction range of $0.14 \mathrm{~T}$ to $0.86 \mathrm{~T}$, the observed linear relationship of $m_{o} M\left(\left(\mu_{0} H\right)^{-1}\right)$ (Fig. 4) suggests that, here, the magnetisation process is governed by microscopic rotations of magnetic moments in the vicinity of quasi-dislocational dipoles. In stronger magnetic fields, a linear relationship of $m_{o} M\left(\left(\mu_{0} H\right)^{1 / 2}\right)$ was observed (Fig. 5). This indicates the presence of the Holstein-Primakoff paraprocess, [18-21], associated with the dumping of thermally-induced spin waves.

Figs. 6-8 present the magnetisation curves for the bulk amorphous alloy of $\mathrm{Fe}_{64} \mathrm{Co}_{10} \mathrm{Y}_{6} \mathrm{~B}_{20}$. In the case of this alloy, within the magnetic field range of $0.25 \mathrm{~T}$ to $0.1 \mathrm{~T}$ a linear relationship of $m_{0} M\left(\left(\mu_{0} H\right)^{-1}\right)$ was observed (Fig. 7). This means that quasi-dislocational dipoles have the predominant influence on the magnetisation process within this magnetic field range. Within magnetic fields of $\mu_{0} \mathrm{H}>1.1 \mathrm{~T}$, the small increase in magnetisation is associated with the HolsteinPrimakoff paraprocess.

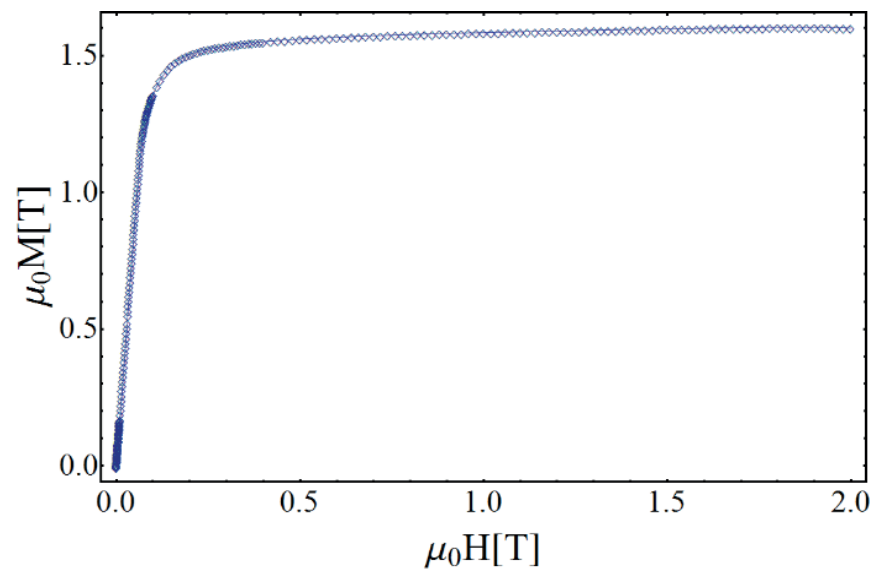

Fig. 6. Magnetisation $(\mathrm{m} M)$ as a function of the magnetising field $\left(\mathrm{m}_{\mathrm{o}} \mathrm{H}\right)$ for the $\mathrm{Fe}_{64} \mathrm{Co}_{10} \mathrm{Y}_{6} \mathrm{~B}_{20}$ bulk amorphous alloy 


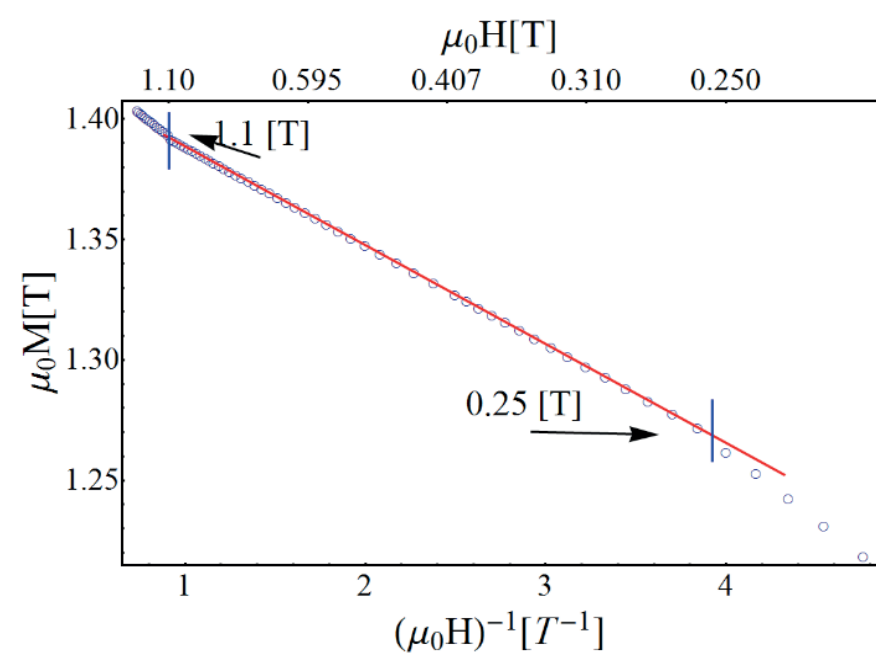

Fig. 7. The high-field magnetisation curve $m_{0} \mathrm{M}\left(\left(\mu_{0} \mathrm{H}\right)^{-1}\right)$ for the bulk amorphous alloy of $\mathrm{Fe}_{64} \mathrm{Co}_{10} \mathrm{Y}_{6} \mathrm{~B}_{20}$ in the as-quenched state

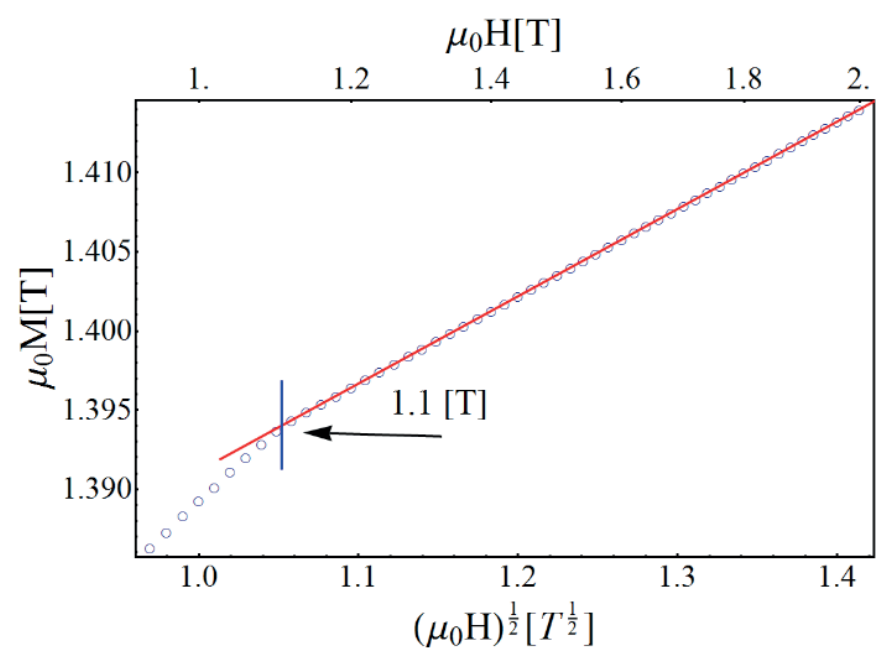

Fig. 8. The high-field magnetisation curve $\mathrm{m}_{\mathrm{o}} \mathrm{M}\left(\left(\mu_{0} \mathrm{H}\right)^{1 / 2}\right)$ for the bulk amorphous alloy of $\mathrm{Fe}_{64} \mathrm{Co}_{10} \mathrm{Y}_{6} \mathrm{~B}_{20}$ in the as-quenched state

Parameters obtained from analysis of the magnetisation curves, presented in Figs. 2-8, are gathered in Table 1.

TABLE 1

Saturation magnetisation $M_{S}$ and experimental values of the $a_{1 / 2}, a_{1}, b$ parameters and the spin wave stiffness parameter $\mathrm{D}_{\mathrm{sp}}$

\begin{tabular}{|c|c|c|c|c|c|}
\hline \hline Parameter & $\begin{array}{c}\mathbf{M}_{\mathbf{S}} \\
{[\mathbf{T}]}\end{array}$ & $\begin{array}{c}\mathbf{a}_{1 / 2} \\
{\left[\mathbf{T}_{1 / 2}\right]}\end{array}$ & $\begin{array}{c}\mathbf{a}_{1} \\
{[\mathbf{T}]}\end{array}$ & $\begin{array}{c}\mathbf{b} \\
{\left[\mathbf{T}_{1 / 2}\right]}\end{array}$ & $\begin{array}{c}\mathbf{D}_{\text {sp }} \\
{\left[\mathbf{1 0}^{-2} \mathbf{e V n m} \mathbf{n n}^{2}\right]}\end{array}$ \\
\cline { 1 - 5 } $\mathbf{F e}_{63} \mathbf{C o}_{10} \mathbf{Y}_{7} \mathbf{B}_{20}$ & 1.60 & 0.23 & 0.02 & 0.048 & 50 \\
\cline { 1 - 4 } $\mathbf{F e}_{64} \mathbf{C o}_{10} \mathbf{Y}_{6} \mathbf{B}_{20}$ & 1.43 & ---- & 0.04 & 0.055 & 46 \\
\hline
\end{tabular}

The saturation magnetisation for the bulk amorphous alloy $\mathrm{Fe}_{63} \mathrm{Co}_{10} \mathrm{Y}_{7} \mathrm{~B}_{20}$ is equal to $1.60 \mathrm{~T}$; the equivalent value for $\mathrm{Fe}_{64} \mathrm{Co}_{10} \mathrm{Y}_{6} \mathrm{~B}_{20}$ has the value of $1.43 \mathrm{~T}$. In addition, the $\mathrm{Fe}_{63} \mathrm{Co}_{10} \mathrm{Y}_{7} \mathrm{~B}_{20}$ alloy was found to yield a higher value of the spin wave stiffness parameter. The $\mathrm{D}_{\mathrm{sp}}$ parameter is connected with the number of magnetic atoms in the nearest neighbourhood. In the case of the $\mathrm{Fe}_{63} \mathrm{Co}_{10} \mathrm{Y}_{7} \mathrm{~B}_{20}$, the higher value of the spin wave stiffness parameter indicates a larger quantity of magnetic atoms within the nearest neighbourhood and smaller distances between them; this leads to the creation of chemical short-range ordering [22-24]. This also explains the higher value of the saturation magnetisation determined for the $\mathrm{Fe}_{63} \mathrm{Co}_{10} \mathrm{Y}_{7} \mathrm{~B}_{20}$ alloy.

\section{Conclusions}

On the basis of the performed investigations, it can be stated that the obtained alloys of $\mathrm{Fe}_{63} \mathrm{Co}_{10} \mathrm{Y}_{7} \mathrm{~B}_{20}$ and $\mathrm{Fe}_{64} \mathrm{Co}_{10} \mathrm{Y}_{6} \mathrm{~B}_{20}$, in the as-quenched state, were amorphous.

Utilising the 'approach to ferromagnetic saturation' theorem, the underlying structure of the amorphous alloys could be investigated indirectly. From measurements of magnetisation under the influence of strong magnetic fields, it was found that the magnetisation process of the bulk amorphous alloys (where domain structure was not observed) was influenced by linear defects (called quasi-dislocational dipoles) and point defects. The type of defect depends on the chemical composition of the alloy. In the case of the $\mathrm{Fe}_{63} \mathrm{Co}_{10} \mathrm{Y}_{7} \mathrm{~B}_{20}$ alloy, the magnetisation process within strong magnetic fields was found to be influenced by both point defects and quasi-dislocational dipoles. However, in the case of the $\mathrm{Fe}_{64} \mathrm{Co}_{10} \mathrm{Y}_{6} \mathrm{~B}_{20}$ alloy, only point defects were found to be involved. For the both of the investigated alloys, in higher magnetic fields the observed increase in magnetisation is associated with the dumping of thermally-induced spin waves (Holstein-Primakoff paraprocess).

On the basis of the magnetisation investigations, it can be stated that a minor change in the chemical composition of the alloys has an influence on the magnetic properties of the materials. The $\mathrm{Fe}_{63} \mathrm{Co}_{10} \mathrm{Y}_{7} \mathrm{~B}_{20}$ alloy is characterised by a higher value of saturation magnetisation $(1.60 \mathrm{~T})$, in comparison to the $\mathrm{Fe}_{64} \mathrm{Co}_{10} \mathrm{Y}_{6} \mathrm{~B}_{20}$ alloy $(1.43 \mathrm{~T})$. In addition, from analysis of the magnetisation curves, the spin wave stiffness parameters for the investigated alloys were determined; this value is also higher for the $\mathrm{Fe}_{63} \mathrm{Co}_{10} \mathrm{Y}_{7} \mathrm{~B}_{20}$ alloy The higher value of this parameter indicates a higher value of the atomic packing density for this alloy.

\section{REFERENCES}

[1] P. Duwez, R.H. Willens, T. Metall. Soc. Aime 227, 362 (1963)

[2] M. Nabiałek, P. Pietrusiewicz, K. Błoch, J. Alloys Compd. 628, 424 (2015).

[3] M.E. McHenry, M.A. Willard, D.E. Laughlin, Prog. Mater. Sci. 44, 291 (1999).

[4] K. Błoch, J. Magn. Magn. Mater., (2015) doi:10.1016/j. jmmm.2015.04.032M

[5] Nabiałek, J. Alloys and Compd., (2015), doi:10.1016/j. jallcom.2015.03.250

[6] E. F. A. Inoue, Mater. Sci. Foundations 6, (1998) TransTech Publications

[7] S. Garus, M. Nabiałek, K. Błoch, J. Garus, Acta Phys. Pol. 126, 957 (2014).

[8] K. Błoch, M. Nabiałek, P. Pietrusiewicz, J. Gondro, M. Dośpial, M. Szota, K. Gruszka, Acta Phys. Polon. A 126, 108 (2014).

[9] H. Kronmüller, J. Appl. Phys. 52, 1859 (1981).

[10] H. Kronmüller, IEEE Trans. Magn. 15, 1218 (1979). 
[11] M. Nabialek, M. Dospial, M. Szota, P. Pietrusiewicz, Mater. Sci. Forum 654-656, 1074 (2010).

[12] H. Kronmüller, J. Ulner, J. Magn. Magn. Mater. 6, 52 (1977).

[13] M. Vasquez, W. Fernengel, H. Kronmüller, Phys. Stat. Sol. 115, 547 (1989).

[14] O. Kohmoto, J. Appl. Phys. 53, 7486 (1982).

[15] [A. Inoue, T. Zhang: Mater. Trans. Jpn. Inst. Met. 36, 1184 (1995).

[16] K. Błoch, M. Nabiałek, Acta Phys. Polon. A 127, 413 (2015).

A. Lukiewska, J. Zbroszczyk, M. Nabialek, J. Olszewski, J. Swierczek, W. Ciurzynska, K. Sobczyk, M. Dospial, Arch. Metall. Mater. Sci. 53, 881 (2008).
[17] T. Holstein, H. Primakoff, Phys. Rev. 58, 1098 (1940).

[18] M. Nabialek, M. Szota, M. Dospial, P. Pietrusiewicz a, S. Walters, J. Magn. Magn. Mater. 322, 3377 (2010).

[19] T. Holstein, H. Primakoff, Phys. Rev. 59, 388 (1941).

[20] M. Nabiałek, M. Szota, M. Dośpiał, J. Alloys Compd., 526, 68 (2012).

[21] B.W. Corb, R.C. O’Handley, N.J. Grant, Phys. Rev. B 27, 636 (1983).

[22] N. Lenge, H. Kronmüller, Phys. Stat. Solid. (a) 95, 621 (1986).

[23] K. Gruszka, M., Nabialek, K. Bloch, J. Olszewski, Nukleonika 60, 23 (2015). 
